\title{
Facing a 'civilisational choice': Images of Europe by the populist radical right in the 2019 European elections
}

\author{
BORIS POPIVANOV \\ Sofia University "St. Kliment Ohridski", Bulgaria \\ Ibpopivanov@phls.uni-sofia.bg
}

\begin{abstract}
This paper deals with the perceptions of Europe as developed by the European populist radical right over the campaign for the 2019 European Parliament elections. The study is based on the public communications of three leading political parties in this spectrum: France's Rassemblement national, Italy's Lega and Germany's Alternative für Deutschland. By applying image theory in international relations, the paper comes to the conclusion that the radical right managed to construct a relatively coherent image of the EU as a distant undemocratic actor in sharp contrast to the alternative narrative of one 'Europe of fatherlands' described in mostly civilisational terms.
\end{abstract}

Key words: alternative narratives, civilisationism, Europe, image theory, populist radical right

\section{Introduction}

Over the recent decades, Euroscepticism has become an increasingly popular catchword in attempts to explain what is happening in the European Union (EU). Paul Taggart (1998), one of the first authors to systematically study and define this concept, points out that it is directed against the concrete political outcomes of the European integration. It is not just scepticism of the idea of Europe. The reasons for its emergence stem from the fact that while the institutional integration of the EU is a clear process, the idea of the EU is much vaguer, allows for different interpretations, and, hence, different mobilisations against one or another of its forms (Taggart 1998., p. 385). Two decades after Taggart's first works on the issue, Liesbet Hooghe and Gary Marks (2018), leading names in EU research, concluded that a new important cleavage had emerged and established itself in Europe, separating the national from the transnational. It runs a dividing line across the political spectrum, from the far left through political formations of the mainstream, to the far right. At the same time, the parties of the populist radical right have a common ground in their Eurosceptic orientation and are able to integrate their voters on this basis (GómezReino \& Llamazares, 2013). These parties are not just strong proponents of Euroscepticism, but they have gradually increased the weight of the Eurosceptic appeal as it is increasingly becoming an essential part of their political identity and a potential field for mutual cooperation (Liang, 2007). While Eurosceptic parties are established to be not against Europe but for "another Europe", there is no agreement on what "another Europe" (Mudde, 2007, pp.165-67) means. 
Researchers of Euroscepticism tend to agree that views on Europe and European unification among the populist radical right vary (McDonnell \& Werner, 2019). However, a specific motif recurs which Rogers Brubaker (2017) summarises as "civilisationism" to denote the shift of emphasis by radical right parties, triggered by the perceived civilisational threat from Islam. 'The nation' is re-characterised in civilisational terms and as a result a new kind of "imagined community" (Anderson, 1983) emerges from the power basis of nationalism while it is not merely reducible to it. This shift does not imply a common doctrine of European cultural identity but rather a set of shared ideas and attitudes. "Civilisationism" (Anderson, 1983) is, first of all, a reactionary mobilisation of Europeanness, one directed against the Other, who is argued not to belong to the European space (Muslims, migrants, sometimes Eastern Europeans or Jews) as supposedly rooted in deeply entrenched and irreversible cultural incompatibility. Secondly, it takes Europe as a restrictive community, broadly historically informed and shaped by values of ancient Greek democracy, Roman legal tradition and Christianity. Thirdly, it invokes the spirit and constructs an idea of a naturally harmonic order of coexisting European peoples, bound and characterised by ethnopluralism and protectionism. Of course, such a dynamic vision is heavily burdened by contradictions and tensions but narratives of "civilisationism" (Anderson, 1983) also carry the potential to unite seemingly opposite groups: the liberal and the conservative, the Christian and the secular. Its endurance over time is questionable but it should be acknowledged that it creates pervasive binaries, drawing on traditionally populist divisions between 'us-them' and 'the elite-the people'. In these binary readings, 'they' - the peoples and nations outside of Europe - cannot be adequately integrated into the exclusive 'us'. The 'elite' symbolised by European institutions - cannot protect the 'people' from imminent threats, not least as understood to emanate from the dangerous Other (Balibar, 1991, pp. 24-27; Betz, 1994, p. 182; Vasilopoulou, 2011, pp. 234-235; De Cesari, Bosilkov \& Piacentini, 2020).

The European Parliament elections in May 2019 were seen as a turning point in the development of European integration. Years earlier, politicians, media and experts had warned that the election could be a breakthrough for the radical right and Eurosceptic groups. The future of the European project seemed to be in doubt and more threatened than ever before, which turns the context and rhetoric prior to the election into a particularly representative and noteworthy phase to examine populist and radical right groups' vision for Europe. This paper principally seeks to answer two research questions: how do radical, populist parties, in this political and ideological space, imagine the EU's Europe; and how do they see and envision the 'other Europe', i.e. the alternative to the current status quo? A review of these 'visions' inevitably presupposes an assessment of their transnational coherence, namely the extent to which they overlap and the extent to which they differ among various representatives of the radical right in different countries in Europe.

The paper proceeds as follows: First, the analysis justifies the case selection in accordance with the theoretical framework and method of research. Subsequently, this paper will discuss images of Europe of three radical right populist groups independently to, then, draw on a comparative discussion and their in-depth characteristics in the conclusion. 


\section{Case selection, theory and method}

In answering the research questions, this paper limits the analysis to three radical-right populist parties: France's Rassemblement National (RN), ${ }^{1}$ Italy's Lega (LN) ${ }^{2}$ and Germany's Alternative für Deutschland (AfD) ${ }^{3}$. There are several reasons for the selection of these three groups for the analysis in this paper. To be sure, the absence of Central and Eastern European cases is noticeable, and the radical right likewise advocates visions of Europe in Central and Eastern (Pirro, 2014, pp. 618-620) (see Deimantaite in this Special Issue). Yet, the focus on Western Europe is driven not by disregard but by an assessment of the potential of radical-right groups to influence large audiences. Influence in this paper is assessed by electoral performance and by self-perceived representations of the parties as being from founding nations of Europe. This paper refers to three lead-EU member states, whose domestic political processes undoubtedly have pan-European effects. The three examples are also interesting from the point of view of international cooperation among the radical right. Despite AfD's initial leaning towards the European conservative family, all three parties eventually joined the new radical right political group Identity and Democracy in the European Parliament.

To examine if 'another Europe' was gaining momentum during the 2019 election campaign, this paper argues it useful to clarify what images of Europe are behind the messages of the radical right. Existing perceptions of the EU, as already established, can influence the support of, or opposition to, European integration (Mišík, 2013, pp. 456-57). In this paper, influence is understood through the role and strategic use of alternative narratives in telling the story of Europe in the $21^{\text {st }}$ century. Strategic narratives are defined as instruments of political actors to construct a "shared meaning of the past, present, and future of international politics to shape the behaviour of domestic and international actors" thereby determining "who we are" and "what we want" on the path to exerting influence over others (Miskimmon, O'Loughlin \& Roselle, 2014, p. 2). "Alternative narratives' (see Introduction to the Special Issue) are challengers to existing interpretations that aim to not simply eliminate the opponent's narrative but also destroy the conditions which make it viable (Miskimmon, O'Loughlin \& Roselle, 2014, p. 104). So far, the scholarship in strategic narratives has not paid sufficient attention to the role of political parties as narrators in the space of narrative contestation.

While strategic narratives shed a light on the identity of a political actor, the latter's images of Self and Others may clarify their role and behaviour in politics. That is why, beside strategic narrative theory, this paper also draws on image theory in international relations. Three discourses inform image construction: elite opinion, media framing and public opinion (Chaban, Elgström \& Gulyaeva, 2017). This paper is interested in the opinion of the radical right's elite actors, in other words, of leaders of the respective parties and their representatives who drive campaigns. Images include certain dimensions: the intentions of a political actor to either preserve or revise the status quo; a perception by others of the actor's power as rising or declining; a view of domestic structures and norms that reveal cultural, economic and political settings. Images relate both to others (external images) and to ourselves (internal images). Stereotyped images - friends, powerful friends,

\footnotetext{
${ }^{1}$ Until June 2018 the party was called the National Front (Front National) which is still its more popular name compared to the current one, the National Rally.

${ }^{2}$ In 2018 the party which had been previously called Lega Nord (the Northern League) was rebranded as just Lega (League). Nevertheless, it is still more popular under its previous name and that is why this paper sticks to the abbreviation LN.

${ }^{3}$ In English: Alternative for Germany.
} 
enemies - can emerge as a combination of characteristics perceived along these dimensions (Elgström, 2000, pp. 3-6, 73-75). Through the components of such images, scholars can assess whether the images that different actors create, suggest an opportunity or a threat (Herrmann, 2013, p. 340). The radical right in the 2019 European elections offers a pertinent opportunity to test the theory. The "tricky" point in this paper is to disentangle the mixture of "images of a political project ('the EU') and a fuzzy dream of identity ('Europe')” (Didelon-Loiseau \& Grasland, 2014, p. 92).

The approach in this paper is based on a qualitative critical discourse analysis of political communication. It is employed as a problem-oriented method through which texts are examined for properties that have contributed to their ideological shaping in order to reproduce the discursive reality and critically examine identities and visions proposed by political actors (Wodak \& Meyer, 2001). The task is to identify references to 'Europe', and correspondingly 'European', 'EU' and 'Brussels', by coding the appropriate language units in relation to Europe's intentions, capabilities and status. The paper will proceed by contextualising and interpreting the main image components in the data. It draws on two channels of communication: the election manifestos and the official Twitter accounts of each party (RN, 2019a; RN, 2019b; LN, 2019; AfD, 2019a; AfD, 2019b).

While the former allows tracing a more strategic vision of the political actors, the latter represents its practical development and prioritisation in the course of the election campaign. It should be noted that one of the political forces -- Italy's LN -- never published its manifesto but claimed to adhere to the program of the European radical right party family (Tronconi \& Valbruzzi, 2020) The preference for Twitter compared to other social media networks stems from the fact that the media allows for short and clear messages and is frequently used by all three political parties and is used with the highest intensity. Statuses posted on Twitter are also accompanied by intertextual links to articles and videos in other media, which have also been subject to examination in this paper. This paper starts the examination from 26 March 2019 - two months prior to Election Day because it is when the campaigns actually start, and the European theme increases in relative shares, and ends with the Election Day on 26 May 2019 (see Table 1).

Table 1: Radical right's coverage of Europe on Twitter from March 26, to May 26, 2019.

\begin{tabular}{|l|l|l|l|}
\hline Political party & RN & LN & AfD \\
\hline $\begin{array}{l}\text { Total number of } \\
\text { tweets (excluding } \\
\text { replies) }\end{array}$ & 1306 & 2273 & 234 \\
\hline $\begin{array}{l}\text { Tweets referring to } \\
\text { Europe }\end{array}$ & 291 & 149 & 166 \\
\hline
\end{tabular}

\section{RN's perceptions}

The EU in the eyes of France's RN is built against the European peoples ('cette UE qui se construit contre les peuples', RN, 2019a, 23.05.). It is narrated to threaten normal lives and as failing to protect its own (European) businesses and citizens. Europe in this view seeks to anesthetise nations from their memories and is driven by greed and selfishness with the intent to establish a harmful dictatorship of the economy over nations. $\mathrm{RN}$ views the EU's ambition as intending to destroy the most important political asset of modernity: the nation-state. RN argues that the EU's 'open-door policy' has left European societies 
with a "civilisational choice" ("choix de civilization", $\mathrm{RN}, 2019 \mathrm{a}, 21.05$.$) , 'Africa or us' and$ has already opted against the will of its members.

The alternative advocated by RN mirrors the alleged status quo. In terms of purposes, 'the other Europe' supports, takes care, promotes local businesses, protects jobs and borders and defends fatherlands, in particular the conception of the "Home of France" ( $L a$ Maison France", RN, 2019a, 20.05.). In contrast, the EU is perceived as lurking darkly and uncertainly behind its shiny façade. Further, the EU is described as a realm of unfulfilled promises. The EU, according to $\mathrm{RN}$, is no longer a dream for Europeans but a concern that requires a deep change as it is stuck in a paralysis behind big words and vague ideas.

$\mathrm{RN}$ thus proposes that the EU needs replacement by a respectful alliance of nations which should regain and promote Europe's international authority. Moreover, RN suggests that its alternative vision of Europe will prove to be a successful barrier against globalism and uncontrolled capitalism, and, thus favouring local interests of Europeans.

The current EU, RN claims, is not equipped to address the demands of today and the Union is presented as detached from international realities; it is metaphorically conceptualised as the "eunuch of history" ("eunuque de l'histoire", RN, 2019b, p.12). Behind the EU's ambitions looms the desire to unify everything, stifle creative energy and impose low standards. According to the party, the EU does not develop popular affiliation with itself; on the contrary, it crushes all other affiliations and needs to be reminded that "our fatherland is not Brussels" ("Notre patrie ce n'est pas Bruxelles", RN, 2019a, 10.05.).

Moreover, $\mathrm{RN}$ seeks to focus on the shortcomings of globalisation: the lack of identity, expressed in the indiscriminate expansion and intrusion of the "utopia of a Europe without borders" ('utopie d'une Europe sans frontières', RN, 2019a, 17.05); the lack of tradition that has turned the whole of Europe into a "gigantic market" ("un gigantesque marche”, RN, 2019a, 07.05) into which cheap products from all over the world are poured and thus set to ruin local producers; the lack of democracy that handed over the power of the European peoples to an unelected European Commission, which in turn makes the behaviour of Brussels' institutions totalitarian and anti-democratic.

Further, the EU is narrated as rigid and dogmatic and relies on outdated concepts of free movement and competition; in fact, the EU is regarded as helpless in handling the demands of the modern world by adhering to no other standards than market logic. It is likened to a "hampered giant" ("un géant entravé", RN, 2019b, p.16) who walks blindly against the course of history and the world. In the long run, it is narrated as resembling the communist doxa on the eve of the fall of the Berlin Wall, stuck in repetitious cycles of historical clichés, and left with nothing but irreparable disappointments as to their empty promises and policies that are bound to betray expectations.

In contrast to the past, $\mathrm{RN}$ underlines the coherence and continuity of their desired Europe in contrast to the EU. First, unlike the EU, this Europe has a history and the EU's 60 years of existence are a short amount of time in the grand cycle of Europe's thousands of years of development, which emphasises Europe's unique viability and resistance. The "genius of nations" ("le génie propre des Nations", RN, 2019b, p.3) has made it possible to survive while so many others did not. Second, unlike the EU, this Europe has tradition. $\mathrm{RN}$ insists on Europe being not an ideological construction but rather a living reality which is predisposed to look at the future because of its authentic powerbase, i.e. the civilisation 
that invented nations. $\mathrm{RN}$ narrates borders as natural and alien to petty political speculations, in fact, timelessly valid. In this narrative, who belongs to Europe is not for politicians to decide but a natural deliberation of geography, history, and civilisation. Third, unlike the EU, Europe has a democracy that arises from the will of nations. In this view, the strength of cultures and their inbuilt wisdom become the bulwark against extremism and separatism and against non-Europeans who incite European conflicts. In RN's view, Europe makes the nations and they make Europe.

In terms of a short assessment, RN employs anti-globalist and anti-liberal positions to merge them with a strong emphasis on a national romanticism.

\section{LN's perceptions}

Italy's LN narrates the EU as having caused too many disasters. The Union wants to demonstrate the inferiority of member states publicly so that their ministers stay on the side-lines of power. According to LN, the EU also seeks to deprive European nations of having a say in multilateral agreements and from exerting international influence. Instead, the EU is understood to serve other interests because it encourages the spread of criminal activity across Europe, while its leaders indulge in a hedonistic lifestyle which, however, according to LN narrative, is doomed to end soon. LN claims that through its policies, the EU has brought the European nations to a fateful choice between saving Europe and leaving an "Islamic state based on fear and precariousness" ("uno stato islamico fondato sulla paura e sulla precarietà", LN, 2019, 12.05) to the children of Europe and future generations.

LN is convinced that saving Europe means a willingness to defend its community, family, rights, values, rules, culture, history, tradition, and (Christian) religion. LN's desired Europe should look to protect and control its borders and not engage in fruitless ideological debates such as those opposing communists and fascists. In this way, LN claims to go beyond Italian history's radical trends and stick to the 'common sense' of 'common Italians'.

The EU's resources are considered important because necessary reforms could only be achieved through the acting European institutions but according to LN, European elites are consciously weakening these resources by focusing on efforts to relegate important spheres of control to international organisations such as the WTO. In doing so, LN argues the EU takes power from European citizens and willingly hands it to foreigners. In contrast, LN's description of desired change is only vague. The power of Europe should be strong enough to protect its external borders and the 'made in EU' trademark vis-à-vis the outside world but weak enough to promote strong nation-states.

Further, LN claims that what characterises the EU now is an idea, drowning in past illusions and detachment from people. The Union is said to have betrayed its fundamental principles and has ended up creating more obstacles for citizens instead of helping them. Brussels' elites are presented as living in nostalgic self-delusions while, at the same time, their project based on just business and finance has turned from "a dream into a veritable nightmare" ("non è un sogno ma un incubo", LN, 2019, 08.04.). LN sketches an image of the distance from Brussels to ordinary citizens but also the elites' greediness by drawing on the recurring metaphor of "palaces inhabited by the European bureaucrats" ("palazzi dei burocrati europei", LN, 2019, 11.04). For LN, the EU of today is an embodiment of the 
alliteration: "burocrati, banchieri, buonisti o barconi" ("bureaucrats, bankers, advocates of tolerance, barges of immigrants”, LN, 2019, 29.04).

LN's suggested alternative to Europe, in contrast, has to be attractive to everybody inside: "a future Europe where Europe's children can dream" ("l'Europa in cui $i$ nostri figli possono sognare”). LN sees Europe's strength as derived from a historical 'truth', i.e. the inheritance of a great civilisation with Christian roots. This civilisation brings together the legacy of Jerusalem, Athens and Rome and proves simultaneously that Italy's place in the European family is 'natural' and indispensable. LN appears to argue that Italianising Europe is pivotal for the transformation of the Union and it takes "bringing more Italy to Europe" ("portare più Italia in Europa", LN, 2019, 24.05.). Finally, LN seeks to reaffirm a conception of Europe as a place of "security, peace, identity, work and family" ("sicura, di pace, identità, lavoro e famiglia", LN, 2019, 02.05.).

LN's overall stance may be revealed as one of anti-elitism and cultural traditionalism presented as a constant struggle for national self-affirmation.

\section{AfD's perceptions}

Germany's AfD sees the EU as having devastating effects on nation states, cultures, and citizens. Firstly, the EU is portrayed as increasingly and unduly interfering with national issues and thus endangers their sovereignty. Through the introduction of the single currency and its migration policies, the EU is considered to incite conflict among nations, and what is more, makes Germany pay for other countries' debts. Secondly, the AfD argues that the EU seeks to replace nations by "communalising" ("Vergemeinschaften", AfD, 2019a, 23.05) them and, thus, intends to artificially create a uniform European culture, which erodes 'real' cultures. Thirdly, the AfD argues that the EU ignores citizens and their interests and by opening gates to migration it marginalises local populations in a shrinking and ageing Europe. The EU is depicted as unable to do what it wants but powerful enough to destroy what it rejects.

In general, the current EU is narrated as lagging behind the standards of democracy and transparency; it functions as an undemocratic construct, shaped by large and expensive bureaucracies. It ultimately has become a real "bureaucratic monster" "bürokratisches Monster", AfD, 2019a, 23.04) which pays salaries that exceed that of the German Chancellor herself. For the AfD, the EU lives in a separate world characterised by "lobby madness" ("Lobby-Wahnsinn", AfD, 2019a, 03.05), a world in which all important decisions are made behind the scenes of its façade politics. Worse, the EU, in the view of AfD, draws on the past and resembles the former totalitarian East Germany while it dreams of a "European super-state" ("Europäischer Superstaat", AfD, 2019b, p.11). For the AfD, this "super-state" ignores the distinct cultural identities of nations, while the EU has no common cultural identity.

The AfD suggests that Europe should, instead, limit its purpose strictly to an agreement between European states based on mutual recognition and non-interference. The AfD envisions a Europe that is reduced to its core tasks, fostering opportunities for national development of each member state, which means that cooperation is considered useful only where several states can do better than a single one. The AfD's vision involves no common regulatory bodies, common structures of governance or joint long-term strategies, such as a parliament, a common currency, a common army. The AfD thus 
proposes an "intergovernmental association" ("zwischenstaatlicher Zusammenschluss", AfD, 2019b, p. 13).

The AfD labels its alternative to the "super-state", a "Europe of fatherlands" ("Europa der Vaterländer", AfD, 2019b, p. 7). It derives its legitimacy from century-long traditions of popular sovereignty and democracy, dating back to the Enlightenment. For the AfD this means that today such a Europe should not permit the domination of a country by another country, should not infringe upon national responsibilities and sovereignty, and should 'preserve' the integrity of national culture and language. Europe itself is narrated to be a "fortress" ("Festung Europa", AfD, 2019a, 20.05.) which, firstly, allows for only a limited number of legal migrants as, according to the AfD, there is no "human right to Europe" ("Menschenrecht auf Europa", AfD, 2019a, 07.05.), and secondly, keeps a traditional vision of lifestyle and culture that denounces the "unrealistic ideologies" ("wirklichkeitsfremde Ideologien", AfD, 2019b, p.17) of European elites.

In short, AfD is developing some version of protective nationalism marked by simultaneous appeals to conservative identities and political pragmatism.

\section{Conclusions}

The three examined political parties developed strategic narratives of Europe in accordance with their traditions, the domestic political context and the current situation. The differences in emphasis are therefore unsurprising. However, this study also finds a more or less coherent general perception that share similarities and is, therefore, also relevant for a transnational reading of the populist radical right (see Table 2).

Table 2. Image of the EU among the radical right parties

\begin{tabular}{|l|l|l|l|l|l|}
\hline $\begin{array}{l}\text { Political } \\
\text { Party }\end{array}$ & Intentions & Capabilities & Status & Evaluation & Stereotype \\
\hline RN & Evil & Weak & Inferior & Threat & Enemy \\
\hline LN & Evil & $\begin{array}{l}\text { Strong, on } \\
\text { the decline }\end{array}$ & Inferior & Threat & Enemy \\
\hline AfD & Evil & Strong & Inferior & Threat & Enemy \\
\hline
\end{tabular}

In all three cases, the EU stands in opposition to 'Europe', which extends temporally ('past' vs. 'future') and epistemologically ('utopia' vs. 'realism'). The EU is characterised mostly negatively and described in terms of bureaucratic control, administrative negligence, alienation from people, unrepresentative policies, materialist pursuit of profits, globalist aspirations of unification of everything and at all costs, dogmatism and inadaptability, and ultimately is said to resemble communist totalitarianism. Brussels serves to symbolically materialise this description of the EU, and the alternative narrative of the 'other Europe' enables juxtaposition to the negatively connoted EU. This 'other Europe', advocated by all three parties, presupposes respect for the 'will of the people', rejects mass migration, protects national identity, culture and language, is 'loyal' and confined to Europe's historical and spiritual roots, mostly narrated through traditional values. All three parties, thus, envision their dream of the 'other Europe' as a 'Europe of the Fatherlands.' In all similarities, some principal differences between the parties are evident. Such differences, 
for example, concern issues of ecology, religiousness, and taxation. The disagreements in the evaluation of the EU's capabilities are, however, superficial and the commonalities remain dominant.

While the image of the EU is constructed as external to the parties and the European peoples, the EU as a political actor shares the same physical space with its opponents. Europe appears to be the "ontic space" for the radical right. "Ontic spaces" (Ejdus, 2017; Ejdus, 2020) relate to material environments incorporated into state identity narratives as spatial extensions of the collective Self. The introjection of "ontic spaces" denotes the process of absorption of the material environment in the project of the Self for the purposes of self-assertion (Ejdus, 2017; Ejdus, 2020). Non-state actors such as radical right parties seek to develop a similar territorial materialisation of desire. Europe is the "ontic space" (in the above sense) that can justify and provide territorial materialisations of their nationalist agendas, while serving as the land that substantiates the claim to the 'other Europe'. The radical right seeks to present its political identity as the imaginary shared identity of the EU member states and their peoples, which, in turn, requires the territory of Europe. In short: the EU must be taken out of Europe. The alternative narrative of Europe is outlined in such a way as to suggest naturalness. It is not an issue of replacing one European order with another. The issue is to replace the non-European, in other words the external, with the 'natural' European, or otherwise the internal. Image theory allows for an understanding of how the political behaviour of certain actors enables the narratives and perceptions they construct.

The campaign for the 2019 European Parliament elections certainly proves that narratives and images of Europe on the populist radical right are seminal to the self-representation of this political camp and suggest important routes for research in European politics.

\section{Acknowledgments}

Many colleagues contributed to this research with critical comments and suggestions for improvement. I would like to thank in particular Natalia Chaban, Pauline Heinrichs and Muriel Pluschke. It goes without saying that the usual disclaimer applies.

\section{References}

AfD (2019a). Offizieller Account. https://twitter.com/AfD

AfD (2019b). Programm für die Wahl zum 9. Europäischen Parlament 2019. https://www.afd.de/wpcontent/uploads/sites/111/2019/03/AfD Europawahlprogramm A5hoch web 150319.pdf

Anderson, B. (1983). Imagined communities: reflections on the origin and spread of nationalism. London: Verso.

Balibar, E. (1991) Is There a 'Neo-Racism'? In E. Balibar \& I. Wallerstein. Race, Nation, Class: Ambiguous Identities (pp. 17-28). London and New York: Verso.

Betz, H.-G. (1994). Radical Right-Wing Populism in Western Europe. Basingstoke and London: Macmillan. 
Brubaker, R. (2017). Between nationalism and civilizationism: the European populist moment in comparative perspective. Ethnic and Racial Studies, 4O(8), 1191-1226.

Chaban, N., Elgström, O., \& Gulyaeva, O. (2017). Russian Images of the European Union: Before and after Maidan. Foreign Policy Analysis, 12(2), 480-499.

De Cesari, C., Bosilkov, I., \& Piacentini, A. (2020). (Why) do Eurosceptics believe in a common European heritage? In C. De Cesari \& A. Kaya (Eds.). European Memory in Populism: Representations of Self and Other (pp.26-46). London and New York: Routledge.

Didelon-Loiseau, C. \& Grasland, C. (2014). Internal and External Perceptions of Europe/the EU in the World through Mental Maps. In N. Chaban \& M. Holland (Eds.). Communicating Europe in Times of Crisis: External Perceptions of the European Union (pp.65-94). Basingstoke: Palgrave Macmillan.

Ejdus, F. (2017). 'Not a heap of stones': material environments and ontological security in international relations. Cambridge Review of International Affairs, 3o(1), 2343.

Ejdus, F. (2020). Crisis and Ontological Security: Serbia's Anxiety over Kosovo's Secession. Cham: Palgrave Macmillan.

Elgström, O. (2000). Images and Strategies for Autonomy: Explaining Swedish Security Policy Strategies in the $19^{\text {th }}$ Century. Dordrecht: Kluwer.

Gómez-Reino, M. \& Llamazares, I. (2013). The Populist Radical Right and European Integration: A Comparative Analysis of Party-Voter Links. West European Politics, 36(4), 789-816.

Herrmann, R. (2013). Perceptions and Image Theory in International Relations. In L. Huddy, D. Sears, \& J. Levy (Eds.). The Oxford Handbook of Political Psychology (2nd ed., pp.334-63). Oxford and New York: Oxford University Press.

Hooghe, L. \& Marks, G. (2018). Cleavage theory meets Europe's crises: Lipset, Rokkan, and the transnational cleavage. Journal of European Public Policy, 25(1), 109135 .

Liang, C. (2007). Europe for the Europeans: The foreign and security policy of the populist radical right. In C. Liang (Ed.). Europe for the Europeans: The foreign and security policy of the populist radical right (pp.1-32). London and New York: Routledge.

LN (2019). Lega - Salvini Premier Account Ufficiale. Retrieved from https://twitter.com/LegaSalvini

McDonnell, D. \& Werner, A. (2019). Differently Eurosceptic: radical right populist parties and their supporters. Journal of European Public Policy, 26(12), 17611778.

Mišík, M. (2013). How can perception help us to understand the dynamic between EU member states? The state of the art. Asia Europe Journal, 11(4), 445-463. 
Miskimmon, A., O’Loughlin, B., \& Roselle, L. (2014). Strategic Narratives: Communication Power and the New World Order. London and New York: Routledge.

Mudde, C. (2007). Populist Radical Right Parties in Europe. Cambridge and New York: Cambridge University Press.

Pirro, A.L. (2014). Populist radical right parties in Central and Eastern Europe: The different context and issues of the prophets of the patria. Government and Opposition, 49(4), 600-629.

RN (2019a). Account officiel. https://twitter.com/RNational off

RN (2019b). Pour une Europe des Nations. Manifeste pour une nouvelle coopération en Europe.

https://rassemblementnational.fr/telecharger/publications/Manifeste.pdf

Taggart, P. (1998). A touchstone of dissent: Euroscepticism in contemporary Western European party systems. Journal of Political Research, 33(3), 363-388.

Tronconi, F., \& Valbruzzi, M. (2020). Populism Put to the Polarisation Test: The 201920 Election Cycle in Italy. South European Society and Politics, 1-27.

Vasilopoulou, S. (2011). European Integration and the Radical Right: Three Patterns of Opposition. Government and Opposition, 46(2), 223-244.

Wodak, R. \& Meyer, M. (eds.) (2001). Methods of Critical Discourse Analysis. London: SAGE Publications. 